\title{
Digital Platform Ecosystems as Living Labs for Sustainable Entrepreneurship and Innovation: A Conceptual Model Proposal
}

\author{
Grzegorz Baran *(D) and Aleksandra Berkowicz *(D) \\ Faculty of Management and Social Communication, Jagiellonian University, 30-348 Cracow, Poland \\ * Correspondence: g.baran@uj.edu.pl (G.B.); aleksandra.zurowska@uj.edu.pl (A.B.)
}

Citation: Baran, G.; Berkowicz, A. Digital Platform Ecosystems as Living Labs for Sustainable Entrepreneurship and Innovation: A Conceptual Model Proposal. Sustainability 2021, 13, 6494. https:// doi.org/10.3390/su13116494

Academic Editors: Luca Carrubbo, Xhimi Hysa and Francesca Iandolo

Received: 27 February 2021

Accepted: 26 May 2021

Published: 7 June 2021

Publisher's Note: MDPI stays neutral with regard to jurisdictional claims in published maps and institutional affiliations.

Copyright: (c) 2021 by the authors. Licensee MDPI, Basel, Switzerland. This article is an open access article distributed under the terms and conditions of the Creative Commons Attribution (CC BY) license (https:// creativecommons.org/licenses/by/ $4.0 /)$.

\begin{abstract}
The main idea of the paper is to combine modern research methods (as living labs that enable research in a real-life setting) with the new technological opportunities for entrepreneurship and innovation development (as digital platforms) to search for innovative solutions, while addressing the sustainable development problems. Thus, the paper aims to explain how real value for society is created within digital platform ecosystems and how they employ to this end novel solutions that better address existing social problems. Consequently, it proposes a conceptual framework to research and develop sustainable entrepreneurship and innovation with the use of digital platforms. This research study takes a synthesizing conceptual approach that seeks to integrate the existing knowledge drawn on two major streams of research: living labs as a methodology and digital platform ecosystems to enrich the theory of sustainable entrepreneurship and innovation development. The paper contributes to the body of knowledge by proposing a novel conceptual model of digital platform ecosystems as living labs for sustainable entrepreneurship and innovation. The model depicts digital platform ecosystems examined as living labs and the implicit processes that include platform users in problem-solving and value-creation in real-life settings. The novelty of the model stems from framing these processes that capture the relationship between individuals and opportunities as the foundations of entrepreneurship and the relationship between the problem space and the solution space, where the opportunities occur.
\end{abstract}

Keywords: sustainable entrepreneurship; innovation; living labs; digital platform ecosystems

\section{Introduction}

Sustainable entrepreneurship and innovation is recently an intensely debated issue among academics and practitioners [1-6]. This is based on the belief that to make progress on pressing social and environmental issues, it is necessary to transform the way society consumes natural resources and produces energy [7]. Accordingly, there is a growing consensus around ceasing to measure value creation only in economic-financial terms and enhancing research and practice related to the role of entrepreneurs in the implementation of innovations in the context of sustainable development $[2,5,8,9]$.

Given that sustainable entrepreneurship is embedded in the relationship that exists between individuals and opportunities, which leads to social impact through the use of emerging opportunities of sustainable development [8-10], the research framework should assume research in real-life settings, where occasions occur between the problem space and the solution space [11]. While sustainability as a result of implementing the triple bottom line in an entrepreneurial process perspective is research-accessible and can be studied ex-post, the relationship that exists between individuals and opportunities is specific to a given problem, a given entrepreneur, and a given context. Therefore, approaches and methods to study these dependencies in real-life settings are needed.

A proposal for such an approach is a living lab methodology in which the basic idea is to include the users in the value-creation process in real-life settings to observe their 
usage of emerging technologies in the setting of a real-life for several days or weeks [12]. Given that living labs are environments in which user experiences reveal future directions of product development [13], they can be traditional settings (e.g., homes), but also digital environments [12]. In both cases, they consist of networks composed of heterogeneous actors, resources, and activities offering a platform to develop and apply user-driven innovation [13].

Consequently, the paper aims to explain how real value for society is created within digital platform ecosystems and how they employ to this end novel solutions that better address existing social problems. Therefore, the study attempts to examine (1) the relationship between users involved in the development of sustainable entrepreneurship and innovation occurring in digital platform ecosystems, and (2) the contribution of these ecosystems to the processes of identifying social problems and their solutions as sustainable innovations within a real-life setting.

Two knowledge streams - the concept of digital platforms and a living lab methodologyinform the theory of sustainable entrepreneurship and innovation development. Digital platforms are becoming increasingly natural ecosystems for the development and use of innovation, and living labs provide assumptions for innovation research in real-life settings. However, the prospects of a synthesis of these two perspectives remain unclear.

Thus, this research study takes a synthesizing conceptual approach aimed to integrate the prior literature findings into a new conceptual model. The choice of this research problem resulted from the gap identified in the literature study. The literature review proved the significant lack of research studies explaining how real value for society is created within digital platform ecosystems. It could be filled by combining the utility of digital platforms with a living lab method, which would provide a conceptual basis for research and development on sustainable entrepreneurship and innovation.

This paper attempts to fill this gap and aims to answer the question: How could digital platforms be used as living labs for the research and development of sustainable entrepreneurship and innovation in a real-life setting? It contributes to the body of knowledge by integrating the existing findings into a novel conceptual model. The model depicts a focal concept of a digital platform ecosystem examined as a living lab for sustainable entrepreneurship and innovation, and the relationships between its constituents, focusing primarily on implicit processes that include users in problem-solving and value-creation in real-life settings. The novelty of the model stems from framing the implicit processes of value-creating and problem-solution pairing that captures, accordingly, the relationship that exists between individuals and opportunities as the foundations of entrepreneurship and the relationship between the problem space and the solution space, where the opportunities occur. The model proposal needs further operationalization that will allow the use of digital platforms to empirically examine these processes in real-life settings according to a living lab methodology.

After this introduction, the paper's organization follows the logic of the research process. Section 2 contains the review of relevant concepts and theories to build the theoretical background for the study. Then, the research protocol adopted for the study is explained in Section 3. Section 4 contains the research results and the contribution of the study, where the conceptual model of digital platform ecosystems as living labs for sustainable entrepreneurship and innovation is introduced. The results are discussed and concluded in Section 5, where the questions of the importance of the proposed model for the development of digital platforms and how it affects sustainable entrepreneurship and innovations were raised. This section also provides some conclusions and suggestions for future research based on the limitations of the proposed model.

\section{Theoretical Background}

Assuming that conceptual model research seeks to identify previously unexplored connections between constructs or introduce new constructs to explain why components of a process lead to a particular outcome [14], this section provides a review of the extant 
literature drawing on three major streams of research: (1) sustainable entrepreneurship and innovation research, (2) living labs research, especially the research that is focused on the living lab as a methodology, and (3) digital platform ecosystems research focused on the constituents that offer the potential for their use as living labs.

This body of knowledge is the basis of the abductive inference leading to the disclosing of antecedents, outcomes, and contingencies related to the focal constructs defined by the research problem. There is no single theory that provides the theoretical framework for further deliberation. It is the aim of the research study to formulate the proposal of the conceptual model synthesizing the existing knowledge as a conceptual framework for further research.

\subsection{Sustainable Entrepreneurship and Innovation}

Sustainable entrepreneurship and innovation have recently been intensely debated among scholars and practitioners [1-5], while at the same time there is a lack of efficient methods and tools to study such innovations not ex-post, but as the relationship that exists between individuals and opportunities in a given entrepreneurial context. Such an approach could lead not only to better recognition of these processes, but to the creation of new opportunities for their development. Thus, a novel conceptual framework is being discussed in this paper, drawing on existing but still poorly integrated findings on sustainable entrepreneurship and innovation.

There is a growing consensus around the premise that value creation can no longer be measured only in economic-financial terms, by indicators such as sales, profit, or returns on investment (ROI), and be exclusively understood as the maximization of individual profit [5]. Thus, the heated debate in the academic world seeks to build a global framework for pursuing the balance between social, economic, and environmental sustainability [15], and society expects business to incorporate sustainability and environmental concerns into the bottom line [4].

The focal concept of sustainable entrepreneurship and innovation as a body of knowledge and research framework is related to the role of entrepreneurs in the implementation of innovations in the context of sustainable development [2,5,8,9]. It seeks to explain how entrepreneurship and innovation can help resolve the environmental and social problems of global socio-economic systems [4,9]. Given that entrepreneurship is considered as the process of opportunity discovery, creation, and exploitation [4], it can be used as a vehicle for the development and implementation of innovative solutions in the area of sustainability [15]. Thus, an increasing number of researchers study the connection between sustainable development and entrepreneurship, and sustainable entrepreneurship has become, nowadays, a mainstream $[5,16,17]$.

Gast et al. define ecological sustainable entrepreneurship as "the process of identifying, evaluating and seizing entrepreneurial opportunities that minimize a venture's impact on the natural environment and therefore create benefits for society as a whole and for local communities" [4] (p. 46), which, however, can be successfully extended to other nonenvironmental aspects of sustainability. Such was also the dynamics of the development of this body of knowledge-initially, the research was focused on the relationship of entrepreneurial activity with environmental problems and solutions [2,5]. A broader perspective on sustainable entrepreneurship is offered by D. Shepherd and A. Patzelt, who associate it with "the preservation of nature, life support, and community in the pursuit of perceived opportunities to bring into existence future products, processes, and services for gain, where gain is broadly construed to include economic and non-economic gains to individuals, the economy, and society" [10] (p. 142).

In the literature, there are two complementary perspectives on sustainable entrepreneurship. The first stance is based on the premise that entrepreneurship should be subordinated to both exploiting business opportunities and taking account of the environmental and social impact of enterprises in the triple bottom line $[4,5,7,18]$. This draws on the belief that it is necessary to transform the way society consumes natural resources and produces 
energy if we are to make progress on pressing environmental issues [7]. The primary intention of sustainability entrepreneurs is to contribute to improved environmental quality and social well-being in ways that are mutually supportive [18]. Therefore, this perspective assumes that entrepreneurs should seize those entrepreneurial opportunities that minimize a venture's impact on the natural environment and create benefits for society as a whole and local communities [4].

The second perspective offers an enhanced view of the concept indicating that the sustainable development is a substantial source of business opportunities and durable business models, and sustainable entrepreneurship and innovation are mechanisms for addressing these issues $[5,8,10]$. Sustainable entrepreneurship and innovation can help solve social and environmental problems, taking advantage of emerging opportunities [9].

The concept of sustainable entrepreneurship and innovation is two-fold. The first constituent relates to the performance through the relationship that exists between individuals and opportunities, which leads to social impact through the use of emerging opportunities of sustainable development. The other concerns the implementation of the idea of a triple bottom line within a perspective of entrepreneurial processes $[5,8-10]$. The idea of sustainable entrepreneurship is, therefore, a co-existence of the advantages of two complementary realities: entrepreneurship and sustainable development. Entrepreneurs can transform the market and economic structures, making them supportive of environmental and social innovation, and at the same time exploiting those structures as a constituent of their core business activities and a source of competitive advantage [19].

\subsection{The living labs}

Living labs play an important role in the discussed subject, because the use of this approach enables simultaneous problem solving, creating innovations, and allows conducting research and observing how individual processes proceed. This section presents the characteristics of the living labs concept.

The living labs concept appeared at the beginning of the $21^{\text {st }}$ century. It is attributed to architect William J. Mitchell of the Massachusetts Institute of Technology. He proposed to transfer various types of research from laboratories to in vivo environments. This concept was adopted by the European Commission and placed in the common strategic framework of Innovation Europe. The dynamic development of living labs contributed to the creation of the European Network of Living Laboratories. As part of the sustainable development strategy, this concept has been adopted by many prestigious academic universities such as Harvard, Yale, and Cambridge [20] (p. 2).

The living labs became of interest to both people related to the scientific community and people from outside of this environment [21]. Consequently, there are various definitions. Eriksson et al. defined the living labs as "a user-centric research methodology for sensing, prototyping, validating and refining complex solutions in multiple and evolving real-life contexts" [12,21] (p. 4). According to Veeckman et al., a living lab is an emerging approach that engages multiple users to co-create value that leads to innovation [22] (p. 6). Ballon et al. view the living labs as an experimentation environment in which technology is given shape in real-life contexts and in which (end) users are considered "co-producers" [21,23]. The European CoreLabs project defines living labs as a system in which users play a dual role: consumers and co-creators of research, development, and innovation [21,24]. Living laboratories are also structures within which experiences, procedures, and conditions allow for the transformation of ideas into innovations and constitute a long-term social resource that is not related to any specific project [25].

The most important building blocks of living labs, beyond services and methodology, are participation and context. Users should have access to competitive technologies, respect the principles of cooperation and openness, and be involved at all stages of operations. Multicontextual nature, i.e., the observation of man in many aspects of his life (as a citizen, employee, household member, tourist, etc.) [26]. Living labs influenced the change of roles from passive consumers to active prosumers, shortening the time of introducing innovators 
to the market and globalizing the market via the Internet, and IT entering into the daily activities of people [27] (p. 5).

The benefits of using the living labs concept concern: citizens-allows them to develop services and products that meet their real needs and contribute to savings, SMEs: developing and integrating new ideas and quickly expanding local services and products to other, larger markets companies, increasing innovation through cooperation with other companies, but also other users, research entities, economy, and society, which stimulates business-citizen-government partnerships and creates flexible services and ecosystems in the field of technological and social innovation, as well as returns on investment in research and development [28] (p. 7).

Summing up, the uniqueness of the living labs approach consists in combining access to the latest technologies through research involvement, taking contextualization into account through implementation in real environments [29] (p. 796), creating innovation, and at the same time the possibility of observing how this process is going.

\subsection{Digital Platform Ecosystems}

Digital platforms allow transferring the living labs methodology and system to the digital world. As a result, they enable research on the development of entrepreneurship and innovation, not in real-settings but in platform-settings. An important role, from the point of view of the subject matter, is the knowledge of what digital platforms are, the ecosystem of digital platforms, and the mechanisms of their functioning. The following issues apply to these aspects.

Assuming that a platform means a shape or an arrangement of parts that together offer value as a surface onto which something can be placed [30] (p. 2), digital platforms provide applications that provide value to various groups of users at once by the presence of other users [31] (pp. 21-22). The equivalent of this flat structure of traditional platforms is built from the operating system, layered software architecture, a multisided market, a distributed innovation system, a transaction system, apps and digital services, or a data platform [32]. Most digital platforms have three characteristics: they are technologically mediated, enable interaction between user groups, and allow those user groups to do particular things [33,34].

The definitions of digital platforms tend to depend on the domains in which they are studied. The literature distinguishes between technical and non-technical definitions of digital platforms. The technical definitions focus on software development and production. One of them defines digital platforms as "a building block that provides an essential function to a technological system and serves as a foundation upon which complementary products, technologies, or services can be developed" ([35] (p. 364); [36] (p. 1400)).

In the literature, researchers highlight non-technical definitions of digital platforms, which refer to the socio-organizational aspects. Constantinides et al. understand digital platforms as a set of digital resources, be those services, content, or something else, which allow interactions between consumers and external producers [37].

Various conceptualizations of digital platforms exist. Among them can be distinguished: multisided platforms, multisided markets, direct network externalities, indirect network externalities, technical and sociotechnical digital platforms, ecosystem-technical and organizational, applications, boundary resources, platform openness [33].

Gawer and Evans divide platforms according to their principal purpose and identify three different types of digital platforms: transaction platforms, innovation platforms, and integration platforms $[34,38]$. The power of digital transaction platforms comes from their ability to harness a large group of multisided users and the value of the interactions that the platform intermediates between these distinct user groups [39]. Homann-Kee Tui et al. defined an innovation platform as a space for learning, action, and change where groups of individuals (who often represent organizations) with different backgrounds, expertise, and interests come together to diagnose problems, identify opportunities and find ways 
to achieve their goals [40]. Integration platforms combine aspects of the two principal platform types, i.e., transaction and innovation platforms [40].

Users of digital platforms can be divided into groups according to the criterion of purposefulness of use. Consumers, providers: content creators/publisher/advertisers, and platform owners stand out among the groups. Each of them is guided by their own goal when using the platform and the exchange process applies to all groups and involves the simultaneous use of resources that are on the platform, but also the delivery of them [33].

Often, the authors refer to ecosystems in relation to digital platforms. This biological metaphor represents a new form of organization. The interspecies interdependence that occurs in biology is reflected between organizations that work together on the one hand and compete on the other. The ecosystem is an energetically open system, able to persist (self-regulate) and gradually changing (evolving) [41,42]. The ecosystem is, therefore, like an organism with the ability to maintain balance and regenerate.

A digital ecosystem is defined depending on the science in which the concept is used. In the social sciences, a digital ecosystem is a community of users, a shared set of languages, a set of regulatory norms and guidelines to foster trust, a population of services, an opensource service-oriented infrastructure. In the natural science: a population of interacting agents/apps, a distributed evolutionary environment, a dynamic, adaptive, learning and scale-free network infrastructure. Between these two definitions, we have the computer science, where a digital ecosystem is several categories of users, a set of formal languages, a security and identity infrastructure, a service-oriented architecture, a service development environment, a distributed P2P run-time environment, a distributed persistent storage layer [43] (p. 25).

Digital ecosystems are collaborative organizations that are digitally connected, modular, non-hierarchical, specialized, connected, and competing. Their goal is to organize complementary goods and services, which requires cooperation. The end customer does not integrate them himself, but only chooses from a selected set. The ecosystem orchestrator specifies the critical components, sets the terms of engagement, decides who can supplement them, and is not the full owner [44] (pp. 14-15). The trans-functionality of the digital strategy means going beyond traditional functions, business processes, expanding the activities and functions of an organization beyond its boundaries, and transforming the supply chain into a dynamic ecosystem [45] (p. 169).

Hein et al. distinguish three different components that characterize digital platform ecosystems: platform ownership status, ecosystem value creation mechanisms, and the autonomy of complementors [46]. The essential factor in the design and management of digital platform ecosystems is platform ownership $[47,48]$. It is the legal entity that owns and distributes power-centralized or decentralized. Successful digital platforms facilitate value creation mechanisms in the platform ecosystem. These mechanisms are based on the effective and convenient facilitation of transactions [49] and the provision of affordances, making the digital platform a breeding ground for innovation [36]. Complementers' autonomy is the degree of freedom complementers have in co-creating value with the digital platform [50]. Highly autonomous programs are loosely linked to the digital platform and contribute to the variety and number of additions [51]. Complementary elements with little autonomy are closely related to the digital platform and form strategic partnerships that strengthen the basic focal value proposition [52]. Depending on the complementary autonomy, the platform owner has to cope with different levels of control, scalability, and flexibility [53].

\section{Methodology}

This conceptual paper draws on the concept of digital platforms and a living lab methodology as theoretical lenses to inform sustainable entrepreneurship and innovation research. The research study takes a synthesizing conceptual approach, which seeks to integrate the prior literature findings into a new conceptual model by determining new 
relationships among constructs drawing on logical and complete arguments for associations rather than testing them empirically [14,54] (p. 127).

The results of this research take a form of a conceptual model that depicts focal concepts of digital platform ecosystems examined as living labs for sustainable entrepreneurship and innovation, and the relationships between them. The model is primarily focused on those relationships that are salient for including users in problem-solving and valuecreation processes in real-life settings. Since the use of digital platforms as living labs expands the concept of living labs, it requires prior adaptation of this theory according to the methodology of conceptual research based on theory adaptation by introducing a new theoretical lens $[14,55]$.

Thus, the research protocol adopted for the study is based on a multistep research procedure. After exploring the theoretical basis of the study, the analysis of digital platform ecosystems from the perspective of living lab methodology in the context of sustainable entrepreneurship and innovation was prepared to identify focal constructs of the model being developed. Assuming that a model paper typically begins from a focal phenomenon or construct that warrants a further explanation and seeks to identify previously unexplored connections between constructs or introduce new constructs to explain why components of a process lead to a particular outcome and [14], the focal construct has been defined in relation to the adopted research problem as a digital platform ecosystem based on living lab methodology. The other constructs and relationships disclosing antecedents, outcomes, and contingencies related to the focal construct were identified by studying the extant literature findings following the methodology of a model paper $[14,56]$.

The method adopted in this synthesizing research study was abductive reasoning $[57,58]$, which, when combined with coherence theory [59], makes it possible not only to integrate existing theories and phenomena under a novel theoretical umbrella but also to develop hypotheses-as a part of a model being developed - that offer new explanations and open the field for further research. The role of abductive reasoning, in this case, was to identify previously unexplored connections between constructs delivered by already known theories. However, due to the conceptual nature of the study, the reasoning processes are mostly implicit and the moment of insight is difficult to determine (following the heuristic nature of abductive reasoning). It is also difficult to speak of an explicit linear procedure in this kind of research, but rather an iterative process going back and forth between the emerging model and the extant literature. The completion of this iterative process is contingent upon the coherence of the model being created.

In the next step, value-creating processes with user participation and problem-solving infrastructure delivered within digital platform ecosystems have been explored as leading to particular outcomes concerning sustainable entrepreneurship and innovation. The construct "users" was defined broadly as all types of stakeholders involved in the problem solving and value creation processes. This stage was accomplished in accordance with a model paper methodology that seeks to identify previously unexplored connections between constructs, introduce new constructs, or explains why elements of a process lead to a particular outcome $[14,56]$.

As the last step, previously identified constructs have been mapped out, creating a nomological network around the focal construct by employing a formal analytical approach to examine the causal linkages and mechanisms at play and grounding the proposed synthesis in prior literature findings [14]. The relationships between the constructs have been framed as the processes connecting elements of a digital platform ecosystem and participating in problem-solving and value creation regarding sustainable entrepreneurship and innovation development. The results draw on various fields of studies and forms a conceptual framework that requires further studies by follow-up empirical research.

\section{Research Results}

The research study seeks to integrate and synthesize the prior literature findings on digital platform ecosystems and a living lab methodology to contribute to the sustainable 
entrepreneurship and innovation body of knowledge. This raised the research question of what conceptual model could synthesize and integrate the existing findings concerning digital platform ecosystems as living labs for sustainable entrepreneurship and innovation.

The model draws on the fact that the basic idea of a living lab is to include the users in the value-creation process in real-life settings, where they are observed in their usage of emerging technologies for several days or weeks [12]. Living labs as environments in which user experiences reveal future directions of product development [13], can be employed for the research and development of sustainable entrepreneurship and innovation. As networks of heterogeneous actors, resources, and activities that deliver a research think-tank and collaborative development platform to help to apply user-driven innovation practices [13], living labs can be offered within digital platform ecosystems, which introduces a new theoretical lens expanding the traditional ways of applying living labs $[12,60]$.

Thus, the proposed model is the visual representation of those processes engaging users and digital platform infrastructure to solve social problems and co-create sustainable value embedded within the digital platform ecosystem framed as a living lab (Figure 1).

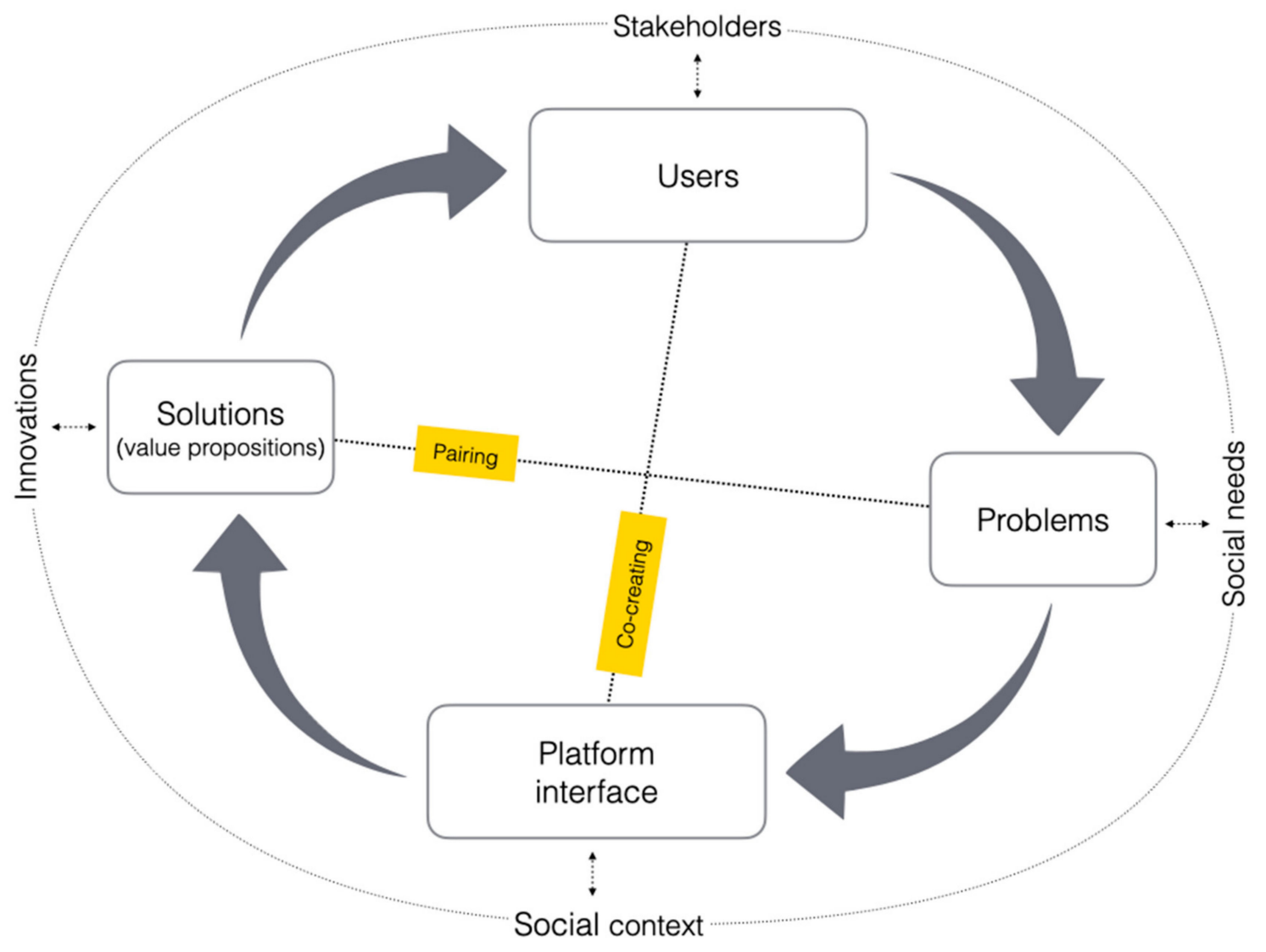

Figure 1. Conceptual model proposal. Source: Own elaboration.

The proposed model includes two interrelated circles made up of the constituents of a digital platform ecosystem as a living lab. The inner circle includes components related directly to the platform ecosystem and forms the core of a living lab. It is composed of four elements: users, platform interface, problems, and solutions that are linked by relationships of a process nature in which these components are jointly involved to create value by proposing solutions to users' problems.

The outer circle is the wider context of a living lab, which cannot be ignored as it has a significant impact on real-life settings within a living lab. This is particularly relevant if we are interested in processes of sustainable entrepreneurship and innovation development. It is composed of four elements: stakeholders, social context, social need, and innovations that provide a broader context for the relevant components of the inner circle. 
Users are all those who are directly registered on the platform and use its infrastructure. However, the operation of the platform has a much broader impact on the environment and other stakeholders. Therefore, the model takes into account the outer circle, which is the broader context of the platform, and which the platform influences, but at the same time, on which the platform also depends. Hence, the category of sustainable entrepreneurship and innovation emerges as such initiatives that take into account the interests of this wider context.

A platform interface is a system or architecture that connects users and enables them to take specific actions [39]. Digital platforms are framed as interfaces between different groups of users that facilitate value-creating exchanges [61]. Platform ecosystems include systems or architectures with a collection of complementary assets [39,62] and actors that provide the platform with complementary goods called complementors [63]. Such networks can generate unlimited innovations through the participation of various actors and resources, and, thus, attracting users who want to satisfy their needs and solve their problems [62].

The platform interface is embedded in a broader social context, which is twofold: constraints on the one hand, and enablers on the other. Constraints are a kind of social pressure, barriers that close the supply of possible actions, and enablers stimulate and provide the opportunities to do certain things. The medium of this social context are the users, who legitimize the interface by the fact that they use it and how they use it. The process of value co-creation, thus, takes place not only between users of the platform infrastructure, but is extended through the inclusion of stakeholders and the social context that sets the structural framework for acceptable activities.

The relationship linking users and a platform interface, and more broadly stakeholders and social context, is framed as a value co-creating process in the proposed model. It helps to capture sustainable entrepreneurship as the performance realized through the relationship between the individual and the opportunity, which is implicit and difficult to determine other than in real-life settings.

This perspective on value creations draws on the premise that the value is embedded in personalized experiences and created by those experiences $[64,65]$. On the theoretical side, the basis for research in this area is value co-creation theory, which consists of: Prahalad and Ramaswamy's proposal of co-creating unique value with customers [64,66], Service-Dominant Logic [67-69], and some other models describing certain aspects of customer involvement in the co-creation of value, for which the common denominator is at least a partial approach to the customer as a part-time employee (e.g., working consumer, prosumer, e-prosumer, open innovation, crowdsourcing).

The main premise of the traditional perspective on value creation was the belief that all value is created within organization boundaries and can be controlled by organizations. The basis of value was considered to be products or services that, in the form of an offer, reach a market understood instrumentally: either as a set of customers representing demand or a place of exchange. This assumption has been questioned by the value cocreation perspective, in which customers are the active co-creator of their own experiences. Those experiences, not products and services, are the vehicle of the value offered on the market $[64,65,70]$.

Problems and solutions as further components of the inner circle, and the "pairing" relationship between them should be considered together. This is due to the nature of the problem formulation and solution development process. Problem-solving research and practice usually begin with the assumption that problem formulation should precede the search for its satisfactory or optimal solution. However, a problem and a solution are discovered as a need/problem-solution pair, and problem identification, if done at all, comes after that discovery. The exception is well-structured problems where the search for underlying causes is done routinely [71].

For innovation, as Dorst and Cross point out, a design process is not so much a creative leap from a problem to a solution as the building of a bridge between the problem space and 
the solution space, which leads to the identification of a key concept by the co-evolution of problem and solution spaces. It involves a period of exploration in which problem and solution spaces are evolving towards the moment of insight at which a problem-solution pair is framed [11]. Problem formulating is a trial-and-error cycle, in which a problemsolution pair is discovered by iterative testing a point in the solution landscape against a point in the need landscape for viability [72]. Schön called this process "problem framing", which is a crucial ability in creative problem solving present in innovation [11,73].

Regarding innovations developed through digital platforms, as Nambisan et al. claim, "innovation problems are primarily associated with unidentified and latent needs of users, customers or other stakeholders, while solutions refer here to digitized artifacts-their features, functionalities, and user affordances-and the surrounding sociotechnical contexts" [74]. This indicates the importance and participation of the relevant components of the outer circle: social needs and innovation, which set the context and the wider community whose needs the solutions created on the platform should address by sustainable entrepreneurship and innovation development. Thus, the problem-solution pairing also expands beyond the platform by associating emerging innovation with social needs, which is particularly important in the context of sustainable entrepreneurship and innovation development.

These two processes described above-value co-creating and problem-solution pairingalthough implicit (which is why they are marked with a dotted line), are the basis for developing ideas for new solutions and ventures. Thus, the model proposal contributes the conceptual framework to examine them. On the other hand, an observable is the linear clockwise process of creating new solutions as a value proposition going from the users around the inner circle: the users (1) have specific needs (2), which we try to recognize within the platform (3) and create solutions (4) dedicated to them.

The contribution of the introduced model is two-fold. First, it delivers the framework to capture the implicit processes of problem-solution pairing and value co-creation taking place in the digital platform ecosystem and realized through user actions mediated by the platform interface. Second, it delivers the framework to examine and understand the role of the wider social context for the processes of using a digital platform to develop sustainable entrepreneurship and innovation. Further operationalization of the model will allow the use of digital platforms to study these processes in real-life settings according to a living lab methodology.

\section{Discussion and Conclusions}

\subsection{Theoretical Contributions}

The aim of the paper was to explain how real value for society is created within digital platform ecosystems and how they employ to this end novel solutions that better address existing social problems. Thus, the paper sought to broaden an extant understanding of the relationship between users and opportunities as the foundations of the development of sustainable entrepreneurship and innovation occurring in digital platform ecosystems, and the matching mechanisms between the problem space and the solution space, where the opportunities occur. To this end, the paper has proposed a conceptual model integrating two streams of existing knowledge-the concept of digital platforms and a living lab methodology - to inform the theory of sustainable entrepreneurship and innovation development. The proposed model visualizes processes involving users and digital platforms in order to solve social problems, co-create value, and develop sustainable entrepreneurship and innovation.

The issues discussed in the article pose a new problem on the basis of current scientific research and explain it theoretically. The result of the undertaken theoretical research is the conceptual model. This article fills the research gap by combining various issues, in the field of new technologies, non-classical methods, and a humanistic approach to life, offering a way to solve social problems creating real value for society. Moreover, it is a proposal of empirical verification of the adopted assumptions. 
Besides contributing to the literature in the form of a model depicting digital platforms ecosystems as living labs for sustainable entrepreneurship and innovation, the paper presents other contributions. The model shows the power of the platform, i.e., the use of technology to connect people, organizations, and resources in any interactive ecosystem in which amazing amounts of value can be created and exchanged [75] by using it to solve social problems and, above all, public, private, and NGO management.

The conceptual framework provides the concept of living labs. A characteristic feature of this concept is to set it in real-settings. In our model, we transfer living labs to platformsettings of the digital world. Currently, many activities take place through digital platforms, this is also more and more often the place of innovation.

The issue of sustainable entrepreneurship is an interesting and at the same time poorly recognized and operationalized research area. There is little or no research on, among others, strategies for implementing sustainable entrepreneurship at the company level, barriers, incentives for sustainable development, social partnership in the field of sustainable entrepreneurship, pro-social and pro-ecological motivations of entrepreneurs, and the lack of measures for assessing the activities of sustainable entrepreneurs [76]. This is because sustainable entrepreneurship is a new research area. The developed model provides a conceptual framework for the study of sustainable entrepreneurship and innovation in statu nascendi, as so far there are no tools and methods to study this issue at the stage of their creation.

The presented model makes it possible to generate "added value", which consists of overcoming the opposition [77] between the values of individual groups of participants. The experience of participating in the co-creation of value for participating entities is the foundation of axiological [77] and socio-cultural relations, not only economic ones.

\subsection{Implications for Practice}

The area where the model can find practical application is management. The presented model assumes the inclusion of users who are the best source of knowledge about needs in the process of creating innovation. Therefore, it becomes possible to implement the concept of public governance, i.e., participatory public management, in which business owners and citizens can be involved in creating solutions and make decisions that directly affect them with a view to sustainable entrepreneurship and development.

Concerning social arguments, the developed model can be used by public, private, and social organizations as well as people, i.e., citizens. It is a platform for meeting the authorities, administration, company owners and employees, and citizens on equal terms, who together solve the problems they face and satisfy real social needs.

The determinants that make up the model offer a chance to avoid economic and moral wastage. The developed model allows for the individualization of satisfying needs, i.e., adapting solutions to the needs of recipients, thus, leading to an increase in the quality of life while paying attention to maintaining sustainable development.

\subsection{Limitations}

The limitations of the study result from the methodological constraints of the applied research design. The first one is a purely theoretical representation of the model. The reality is complex, so applying this model in practice would enrich this article with empirical data, verification of assumptions, and possible modification of the model.

The second limitation is related to the use of the living labs concept. This concept generates high administrative and management costs, its application consumes time [78] and requires people with competence in its use.

\subsection{Future Research Directions}

Further research is needed to establish how the built model works in practice and on this basis to collect empirical data. Conducting empirical research will allow estimating the possibilities and quality of the discussed model application. 
The application of the value co-creation theory may be an impulse for its further development towards platform economy and ecosystem platforms. Such an approach may contribute to the exploration of new areas, e.g., social, which can bring profits, reduce costs and risk of actions taken, but above all build economic value-new skills and competencies, and psychological value - greater satisfaction, sense of recognition, and higher self-esteem [79] for the actors involved.

Author Contributions: Conceptualization: G.B., A.B.; methodology: G.B., A.B.; investigation: G.B., A.B.; resources: G.B., A.B.; data curation: G.B., A.B.; writing-original draft preparation: G.B., A.B.; writing-review and editing: G.B., A.B. All authors have read and agreed to the published version of the manuscript.

Funding: This research received no external funding.

Institutional Review Board Statement: Not applicable.

Informed Consent Statement: Not applicable.

Data Availability Statement: Not applicable.

Conflicts of Interest: The authors declare no conflict of interest.

\section{References}

1. Davis, K. Can Business Afford to Ignore Social Responsibilities? Calif. Manag. Rev. 1960, 2, 70-76. [CrossRef]

2. Elkington, J. Cannibals with Forks: The Triple Bottom Line of 21st Century Business; Capstone: Oxford, UK, 2002; ISBN 978-1-84112-084-3.

3. Porter, M.E.; Kramer, M.R. The Big Idea: Creating Shared Value. How to Reinvent Capitalism-And Unleash a Wave of Innovation and Growth. Harv. Bus. Rev. 2011, 89, 62-77.

4. Gast, J.; Gundolf, K.; Cesinger, B. Doing Business in a Green Way: A Systematic Review of the Ecological Sustainability Entrepreneurship Literature and Future Research Directions. J. Clean. Prod. 2017, 147, 44-56. [CrossRef]

5. Sarango-Lalangui, P.; Santos, J.; Hormiga, E. The Development of Sustainable Entrepreneurship Research Field. Sustainability 2018, 10, 2005. [CrossRef]

6. Baran, G.; Berkowicz, A. Sustainability Living Labs as a Methodological Approach to Research on the Cultural Drivers of Sustainable Development. Sustainability 2020, 12, 4835. [CrossRef]

7. Hall, J.K.; Daneke, G.A.; Lenox, M.J. Sustainable Development and Entrepreneurship: Past Contributions and Future Directions. J. Bus. Ventur. 2010, 25, 439-448. [CrossRef]

8. Gerlach, A. Sustainable Entrepreneurship and Innovation. In Proceedings of the Corporate Social Responsibility and Environmental Management Conference 2003, Leeds, UK, 30 June-1 July 2003.

9. Dean, T.J.; McMullen, J.S. Toward a Theory of Sustainable Entrepreneurship: Reducing Environmental Degradation through Entrepreneurial Action. J. Bus. Ventur. 2007, 22, 50-76. [CrossRef]

10. Shepherd, D.A.; Patzelt, H. The New Field of Sustainable Entrepreneurship: Studying Entrepreneurial Action Linking "What Is to Be Sustained" With “What Is to Be Developed". Entrep. Theory Pract. 2011, 35, 137-163. [CrossRef]

11. Dorst, K.; Cross, N. Creativity in the Design Process: Co-Evolution of Problem-Solution. Des. Stud. 2001, 22, 425-437. [CrossRef]

12. Eriksson, M.; Niitamo, V.-P.; Kulkki, S. State-of-the-Art in Utilizing Living Labs Approach to User-Centric ICT Innovation-a European Approach; Center for Distance-Spanning Technology, Lulea University of Technology: Lulea, Sweden, 2005.

13. Leminen, S.; Westerlund, M.; Nyström, A.-G. Living Labs as Open-Innovation Networks. Technol. Innov. Manag. Rev. 2012, 2, 6-11. [CrossRef]

14. Jaakkola, E. Designing Conceptual Articles: Four Approaches. AMS Rev. 2020, 10, 18-26. [CrossRef]

15. Mio, C.; Panfilo, S.; Blundo, B. Sustainable Development Goals and the Strategic Role of Business: A Systematic Literature Review. Bus. Strat. Environ. 2020, 29, 3220-3245. [CrossRef]

16. Cohen, B.; Winn, M.I. Market Imperfections, Opportunity and Sustainable Entrepreneurship. J. Bus. Ventur. 2007, 22, $29-49$. [CrossRef]

17. Gibbs, D. Sustainability Entrepreneurs, Ecopreneurs and the Development of a Sustainable Economy. Greener Manag. Int. 2006, 63-78. [CrossRef]

18. Parrish, B.D.; Foxon, T.J. Sustainability Entrepreneurship and Equitable Transitions to a Low-Carbon Economy. Greener Manag. Int. 2009, 47-62. [CrossRef]

19. Hockerts, K.; Wüstenhagen, R. Greening Goliaths versus Emerging Davids-Theorizing about the Role of Incumbents and New Entrants in Sustainable Entrepreneurship. J. Bus. Ventur. 2010, 25, 481-492. [CrossRef]

20. Graczyk, P. Embedding a Living Lab Approach at the University of Edinburgh; The University of Edinburgh: Edinburgh, UK, 2015.

21. Bergvall-Kåreborn, B.; Ihlström Eriksson, C.; Ståhlbröst, A.; Svensson, J. A Milieu for Innovation—Defining Living Labs. Available online: https://www.researchgate.net/publication/228676111_A_Milieu_for_Innovation-Defining_Living_Labs\# fullTextFileContent (accessed on 21 January 2021). 
22. Veeckman, C.; Schuurman, D.; Leminen, S.; Westerlund, M. Linking living lab characteristics and their outcomes: Towards a conceptual framework. Technol. Innov. Manag. Rev. 2013, 3. Available online: https://timreview.ca/article/748 (accessed on 21 January 2021). [CrossRef]

23. Ballon, P.; Pierson, J.; Delaere, S. Open Innovation Platforms for Broadband Services: Benchmarking European Practices. In Proceedings of the 16th European Regional Conference, Porto, Portugal, 4-6 September 2005.

24. CoreLabs. Available online: http://www.ami-communities.net/wiki/CORELABS (accessed on 21 January 2021).

25. VINNOVA. Available online: http:/ / www.vinnova.se (accessed on 21 January 2021).

26. Feurstein, K.; Hesmer, A.; Hribernik, K.A.; Thoben, K.D.; Schumacher, J. Living Labs: A New Development Strategy, In European Living Labs-A New Approach for Human Centric Regional Innovation Chapter; Schumacher, J., Niitamo, V.P., Eds.; Wissenschaftlicher Verlag: Berlin, Germany, 2008.

27. Ståhlbröst, A.; Holst, M. The Living Lab Methodology Handbook; Social Informatics at Luleå University of Technology and CDTCentre for Distance-Spanning Technology: Lulea, Sweden, 2012.

28. European Communities. Living Labs for User-Driven Open Innovation; Directorate-General for the Information Society and Media: Luxembourg, Belgium, 2008.

29. Åström, J.; Ruoppila, S.; Ertiö, T.; Karlsson, M.; Thiel, S.K. Potentials and challenges of Living Lab Approach in research on mobile participation. In Proceedings of the 2015 ACM International Joint Conference on Pervasive and Ubiquitous Computing (UbiComp 2015), Osaka, Japan, 7-11 September 2015.

30. Tilson, D.; Sorensen, C.; Lyytinen, K. Platform Complexity: Lessons from the Music Industry. In Proceedings of the 46th Hawaii International Conference on System Sciences, Maui, HI, USA, 7-10 January 2013.

31. Digital Platform Inquiry. Preliminary Report. Australian Competition and Consumer Commission 2018. Available online: https: / / apo.org.au/sites/default/files/resource-files/2018-12/apo-nid209641.pdf (accessed on 20 January 2021).

32. Knut, H. Rolland. Digital Platforms-Perspectives, Concepts \& Cases. 2018. Available online: https://www.uio.no/studier/ emner/matnat/ifi/IN5210/h18/lectures/digitalplatforms-lecture-10sept-2018.pdf (accessed on 14 January 2021).

33. Reuver, M.; Basole, R.C.; Sorensen, C. The digital platform a research agenda. J. Inf. Technol. 2017, 33, 124-135. [CrossRef]

34. Evans, P.; Gawer, A. The Rise of the Platform Enterprise: A Global Survey; Center for Global Enterprise: New York, NY, USA, 2016.

35. Spagnoletti, P.; Resca, A.; Lee, G. A design theory for digital platforms supporting online communities: A multiple case study. J. Inf. Technol. 2015, 30, 364-380. [CrossRef]

36. Yoo, Y.; Boland, R.J.; Lyytinen, K.; Majchrzak, A. Organizing for Innovation in the Digitized World. Organ. Sci. 2012, 23, 1398-1408. [CrossRef]

37. Constantinides, P.; Henfridsson, O.; Parker, G. Introduction-Platforms and infrastructures in the digital age. Inf. Syst. Res. 2018, 29, 381-400. [CrossRef]

38. Gawer, A. Bridging differing perspectives on technological platforms: Toward an integrative framework. Res. Policy 2014, 43, 1239-1249. [CrossRef]

39. Gawer, A.; Cusumano, M.A. Industry platforms and ecosystem innovation. J. Prod. Innov. Manag. 2014, 31, 417-433. [CrossRef]

40. Homann-Kee Tui, S.; Adekunle, A.; Lundy, M.; Tucker, J.; Birachi, E.; Schut, M.; Klerkx, L.; Ballantyne, P.G.; Duncan, A.J.; Cadilhon, J.; et al. What are innovation platforms? In Innovation Platforms Practice Brief 1 ILRI; International Livestock Research Institute: Nairobi, Kenya, 2013.

41. Stańczyk, S. Tożsamość ekosystemów biznesu-Zarys koncepcji. Organ. Kier. 2015, 4, 165-179.

42. Stańczyk, S. Organizational ecosystem and stakeholders view. In search of epistemological logic in management. Int. J. Econ. Bus. Res. 2017, 14, 268-283. [CrossRef]

43. Nachira, F.; Nicolai, A.; Dini, P.; Ła Louarn, M.; Rivera Leon, L. Digital Business Ecosystems; European Commission: Luxemburg, 2007.

44. Jacobides, M.G.; Sundararajan, A.; Van Alstyne, M. Platforms and Ecosystems: Enabling the Digital Economy; World Economic Forum: Geneva, Switzerland, 2019.

45. Olszak, C. Strategia cyfrowa współczesnej organizacji. Studia Ekon. Zesz. Nauk. Uniw. Ekon. Katowicach 2015, 232, $164-177$.

46. Hein, A.; Schreieck, M.; Riasanow, T.; Setzke, D.S.; Wiesche, M.; Böhm, M.; Krcmar, H. Digital Platform Ecosystem, Electronic Markets; Springer: Berlin/Heidelberg, Germany, 2019; Available online: https://www.researchgate.net/publication/337186627_ Digital_platform_ecosystems (accessed on 14 January 2021).

47. Bakos, Y.; Katsamakas, E. Design and ownership of two-sided networks: Implications for internet platforms. J. Manag. Inf. Syst. 2008, 25, 171-202. [CrossRef]

48. Tiwana, A.; Konsynski, B.; Bush, A.A. Platform evolution: Coevolution of platform architecture, governance, and environmental dynamics. Inf. Syst. Res. 2010, 21, 675-687. [CrossRef]

49. Tiwana, A. Platform Ecosystems: Aligning Architecture, Governance, and Strategy; Morgan Kaufmann: Burlington, NJ, USA, 2014.

50. Ye, H.; Kankanhalli, A. User service innovation on mobile phone platforms: Investigating impacts of lead userness, toolkit support, and design autonomy. MIS Q. 2018, 42, 165-187. [CrossRef]

51. Boudreau, K.J. Let a thousand flowers bloom? An early look at large numbers of software app developers and patterns of innovation. Organ. Sci. 2012, 23, 1409-1427. [CrossRef]

52. Danneels, E. Tight-loose coupling with customers: The enactment of customer orientation. Strat. Manag. J. 2003, 24, 559-576. [CrossRef]

53. Parker, G.; van Alstyne, M. Innovation, openness, and platform control. Manag. Sci. 2017, 64, 3015-3032. [CrossRef] 
54. Gilson, L.L.; Goldberg, C.B. Editors' Comment: So, What Is a Conceptual Paper? Group Organ. Manag. 2015, 40, 127-130. [CrossRef]

55. Lukka, K.; Vinnari, E. Domain Theory and Method Theory in Management Accounting Research. Account. Audit. Account. J. 2014, 27, 1308-1338. [CrossRef]

56. Cornelissen, J. Editor's Comments: Developing Propositions, a Process Model, or a Typology? Addressing the Challenges of Writing Theory without a Boilerplate. AMR 2017, 42, 1-9. [CrossRef]

57. Paavola, S. Abduction as a Logic and Methodology of Discovery: The Importance of Strategies. Found. Sci. 2004, 9, 267-283. [CrossRef]

58. Dubois, A.; Gadde, L.-E. “Systematic Combining"—A Decade Later. J. Bus. Res. 2014, 67, 1277-1284. [CrossRef]

59. Shepherd, D.A.; Sutcliffe, K.M. Inductive Top-Down Theorizing: A Source of New Theories of Organization. AMR 2011, 36, 361-380. [CrossRef]

60. Dekker, R.; Franco Contreras, J.; Meijer, A. The Living Lab as a Methodology for Public Administration Research: A Systematic Literature Review of Its Applications in the Social Sciences. Int. J. Public Adm. 2019, 43, 1207-1217. [CrossRef]

61. Stallkamp, M.; Schotter, A.P. Platforms without Borders? The International Strategies of Digital Platform Firms. Glob. Strategy J. 2019, 11, 58-80. [CrossRef]

62. Inoue, Y. Indirect Innovation Management by Platform Ecosystem Governance and Positioning: Toward Collective Ambidexterity in the Ecosystems. Technol. Forecast. Soc. Chang. 2021, 166, 120652. [CrossRef]

63. Boudreau, K.J.; Jeppesen, L.B. Unpaid Crowd Complementors: The Platform Network Effect Mirage: Unpaid Crowd Complementors. Strat. Mgmt. J. 2015, 36, 1761-1777. [CrossRef]

64. Prahalad, C.K.; Ramaswamy, V. Co-Opting Customer Competence. Harv. Bus. Rev. 2000, 78, 79-90.

65. Payne, A.F.; Storbacka, K.; Frow, P. Managing the Co-Creation of Value. J. Acad. Mark. Sci. 2008, 36, 83-96. [CrossRef]

66. Prahalad, C.K.; Ramaswamy, V. Co-Creation Experiences: The Next Practice in Value Creation. J. Interact. Mark. 2004, 18, 5-14. [CrossRef]

67. Vargo, S.L.; Lusch, R.F. Evolving to a New Dominant Logic for Marketing. J. Mark. 2004, 68, 1-17. [CrossRef]

68. Ballantyne, D.; Varey, R.J. The Service-Dominant Logic and the Future of Marketing. J. Acad. Mark. Sci. 2008, 36, 11-14. [CrossRef]

69. Vargo, S.L.; Lusch, R.F. Service-Dominant Logic 2025. Int. J. Res. Mark. 2017, 34, 46-67. [CrossRef]

70. Ramaswamy, V. It's about Human Experiences ... and beyond, to Co-Creation. Ind. Mark. Manag. 2011, 40, 195-196. [CrossRef]

71. von Hippel, E.; von Krogh, G. CROSSROADS-Identifying Viable "Need-Solution Pairs": Problem Solving Without Problem Formulation. Organ. Sci. 2015, 27, 207-221. [CrossRef]

72. Coorevits, L.; Georges, A.; Schuurman, D. A Framework for Field Testing in Living Lab Innovation Projects. TIM Rev. 2018, 8, 40-50. [CrossRef]

73. Schön, D.A. The Reflective Practitioner: How Professionals Think in Action; Basic Books: New York, NY, USA, 1983; ISBN 978-0-465-06874-6.

74. Nambisan, S.; Lyytinen, K.; Majchrzak, A.; Song, M. Digital Innovation Management: Reinventing Innovation Management Research in a Digital World. MIS Q. 2017, 41, 223-238. [CrossRef]

75. Parker, G.; van Alstyne, M.W.; Choudary, S.P. Platform Revolution; W.W. Norton \& Company: New York, NY, USA, $2016 ;$ p. 12.

76. Sołoducho-Pels, L. Sustainable Entrepreneurship Utopian Idea or a New Business Model for the 21 Century. Available online: https:/ / dspace.uni.lodz.pl/bitstream/handle/11089/33312/15_Letycja\%20So\%c5\%82oducho-Pelc\%20-\%20PART\%203.pdf? sequence $=1 \&$ isAllowed $=y$ (accessed on 15 March 2021).

77. Rogoziński, K. Zarzadzanie Wartościa z Klientem; Wolters Kluwer: Warszawa, Poland, 2012.

78. Wiśniewska, M. The suitability of Living Lab concept in the implementation of municipal project. Prace Nauk. Uniw. Ekon. Wroctawiu 2016, 431, 98-106.

79. Ramaswamy, V.; Gouillart, F. Building the Co-creative Enterprise. Harv. Bus. Rev. 2010, 88, 100-109. [PubMed] 